\title{
Profesor Doctor Antonio Del Solar Valenzuela
}

\author{
Enrique Laval $R$.
}

${ }^{6} \mathrm{E}$ 1 doctor del Solar fue un luchador por la vida, uno de los más tenaces enemigos de la muerte. Su ejercicio y enseñanza de la medicina estableció siempre un imperativo moral en el mismo fondo del imperativo científico" .

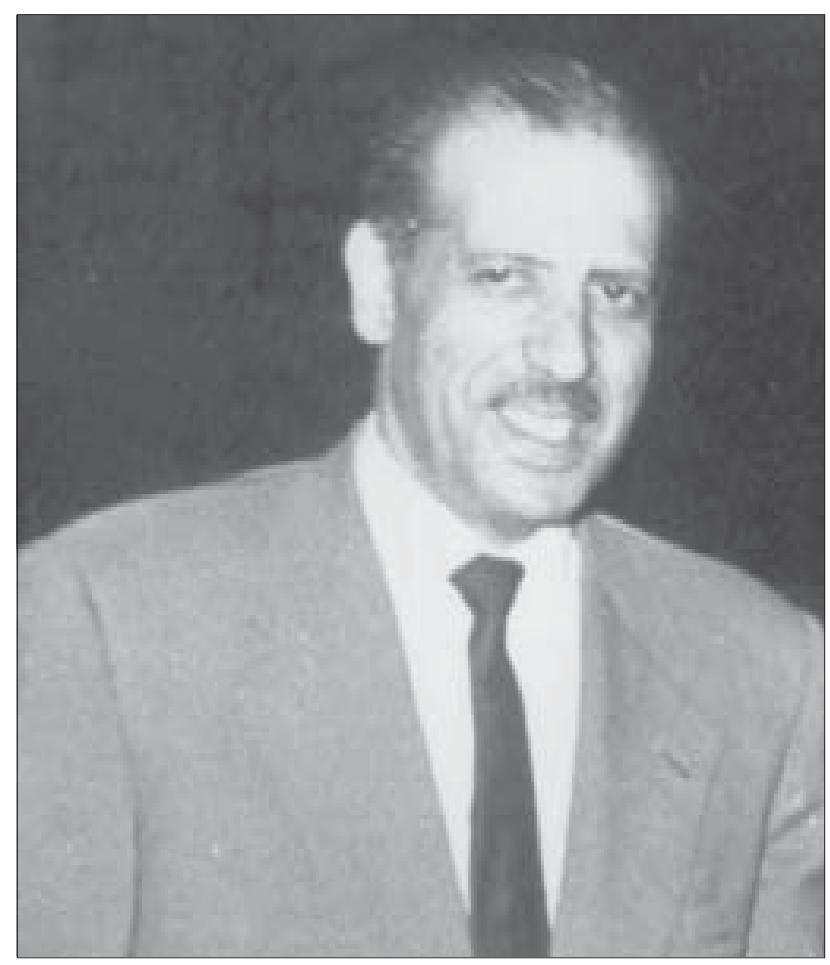

en la Universidad de Chile, donde "fue el mejor alumno de su promoción”. Es digno destacar que los estudios universitarios los inició a la edad de 15 años. En 1934 obtuvo el título de médico-cirujano y su tesis versó sobre "Las alteraciones del aparato cardiovascular en el tifus exantemático".

Comenzó sus actividades profesionales como ayudante de la Cátedra de Patología Médica del profesor Alejandro Garretón Silva, en el Hospital San Francisco de Borja y como médico internista de la Asistencia Pública de Santiago, donde le correspondió, a veces, actuar como médico domiciliario. También se desempeñó en el Servicio Médico de la Caja de Seguro Obligatorio. Realizó actividad gremial como Miembro y Director de la Asociación Médica de Chile (AMECH).

Con el correr de los años, acompañó siempre al profesor Garretón en su Servicio y Cátedra de Medicina Interna, al trasladarse al Hospital José Joaquín Aguirre, actualmente Hospital Clínico de la Universidad de Chi-

Don Antonio del Solar Valenzuela nació en la ciudad de Linares, el día 26 de diciembre de 1910, siendo sus padres don Antonio del Solar Pincheira y doña Adriana Valenzuela Erazo.

Sus estudios secundarios los realizó en el Liceo de Linares; los de Medicina en la Universidad de Concepción y posteriormente le. Ahí llevó a cabo una intensa y fructífera labor docente-asistencial, siendo numerosos los becados de post-grado en Medicina Interna que tuvieron el privilegio de ser formados por él. En 1968 fue nombrado Profesor Titular de Medicina Interna ${ }^{2,3}$.

Al decir de Miguel Laborde, don Antonio del Solar "ejerció la docencia por décadas con brillo y marcó una larga época de 1932 a 1973, atendiendo muchos pacientes de difícil diagnóstico, remitidos por otros médicos. Era cultísimo, informado e intuitivo a la vez. El nombre del doctor del Solar se hizo célebre de boca a boca, por todo Santiago",

Interesante es lo que anota el profesor Kraljevic en sus "Recuerdos de un Viejo Infectólogo": "en algún momento hubo en Chile varios médicos internistas importantes que dedicaron parte de su actividad al estudio y tratamiento de las enfermedades infecciosas, sobresaliendo en este grupo el doctor Antonio del Solar, considerado entre los mejores clínicos del país." A él le interesó sobremanera conocer cabalmente los grandes síndromes de las infecciones no epidémicas y también la difusión de los conocimientos más especializadas sobre quimioterápicos y antibióticos, materias que dominaba con gran maestría. Recuerda el profesor Kraljevic "que en muchas ocasiones estuvo invitado al hogar del doctor del Solar a estudiar juntos en las noches los trabajos más recientes sobre dichos medicamentos", organizando varios simposios, presentaciones en la Sociedad Médica y en algunos hospitales, al igual que el Primer Curso sobre Antibióticos realizado a través de la televisión"4.

En su artículo "La infección en el Siglo XX", el doctor del Solar enfatiza "que le ha tocado vivir el enorme cambio que han experimentado el conocimiento y la terapéutica de las infecciones durante la mayor parte de dicho siglo, lo que constituye uno de los avances más importantes, si no el mayor de la Medicina en todos los tiempos $"$.

Debido a sus grandes méritos y valiosas colaboraciones -concluye el profesor 
Kraljevic- la Sociedad Chilena de Infectología distinguió al doctor Antonio del Solar, designándolo Socio Honorario, el 6 de octubre de 1984, con ocasión de la clausura del Primer Congreso Chileno de Infectología ${ }^{4}$.

La Sociedad Médica de Santiago lo nominó Socio Honorario de la misma y en 1985 dictó la Conferencia de Clausura del VII Congreso Chileno de Medicina Interna, ocasión en que una vez más sobresalió por el conocimiento de las materias abordadas ${ }^{6}$.

De los trabajos publicados por el doctor del Solar en la Revista Médica de Chile, varios sobre enfermedades infecciosas, es interesante destacar los que se refieren a neumonías atípicas, a las producidas por bacterios grampositivo, gramnegativo, anaerobios e indicaciones de terapia

\section{Referencias}

1.- González C O. En recuerdo de don Antonio del Solar. Vida Médica 1986, 37: 38-9.

2.- Diccionario biográfico de Chile.- $6^{\mathrm{a}}$. Edición. 1946-1947. p. 1048 Edit. Europea Periodística de Chile.

3.- Laborde D M. Medicina Chilena del siglo XX (Reseña histórica). 2002. p. 119. Ed. Corporación farmacéutica Recalcine. Santiago, Chile.

4.- Kraljevic R O. Recuerdos de un viejo antibiótica. Asimismo, el ya mencionado sobre "La infección en el siglo XX" y muy especialmente el de "Shock tóxico por Staphylococcus aureus", en que revela una gran claridad de pensamiento y precisión de conceptos, subrayando que "debido al brote epidémico de este síndrome que se produjo en EUA, entre fines de 1979 y 1980, provocó gran impacto en la población norteamericana, siendo motivo de extensos estudios de numerosas publicaciones, que contribuyeron a esclarecer parcialmente su etiopatogenia ${ }^{5,7,8-11}$.

El doctor Antonio del Solar se casó con doña Yolanda Hansen Fuenteseca, con quien tuvo tres hijos, de los cuales dos son médicos: Antonio y Fernando, este último, distinguido infectólogo.

Infectólogo. 1998, Santiago de Chile p. 120-1.

5.- Del Solar V A. La infección en el siglo XX. Rev Méd Chile 1986; 114: 681-6.

6.- Del Solar V A. Obituario. Rev Méd Chile 1987; 115: 285.

7.- Del Solar V A, Gómez Rogers C, Garrido J. Shock tóxico: una toxemia por Staphylococcus aureus. Rev Méd Chile 1987; 115: 216-8.

8.- Godoy P, Del Solar V A. Neumonías atípicas. Rev Méd Chile 1982, 110: 82-7.
Falleció el 19 de octubre de 1986, próximo a cumplir los 76 años. Había sido elegido Miembro de la Academia de Medicina del Instituto de Chile, no alcanzando a incorporarse debido a su deceso.

"Sé que estás conmigo porque siento tu presencia todos los días, por eso no tengo pena, pero no puedo evitar derramar una lágrima de vez en cuando, pues hombres como tú se dan sólo una vez en la vida. Gracias por haber sido mi padre. Gracias, Señor, por tenerlo a tu lado”. Palabras de despedida a su padre, del doctor Fernando del Solar Hansen ${ }^{12}$.

Realmente, don Antonio del Solar fue un verdadero Maestro de la Medicina, destacando por su idoneidad y sólida cultura humanista.
9.- Del Solar V A. ¿Qué antibiótico debe usarse en una neumonía? Rev Méd Chile 1982, 110: 79-81.

10.- Del Solar V A, Godoy P. Neumonías producidas por bacterios gram negativos y anaerobios. Rev Méd Chile 198; 109: 1214-8.

11.- Del Solar V A, Godoy P. Neumonías por bacterios gram positivos. Rev Méd Chile 1981; 109: 1115-8.

12.- Del Solar H F. Don Antonio del Solar, mi padre. Vida Médica 1986; 37: 39. 